\title{
FAKTOR-FAKTOR YANG MEMENGARUHI PENGUNGKAPAN TATA KELOLA PERUSAHAAN DAN DAMPAKNYA TERHADAP KINERJA PERUSAHAAN
}

\author{
Putriana Salman \\ Nurkholis \\ Endang Mardiati
}

Program Pascasarjana Fakultas Ekonomi dan Bisnis Universitas Brawijaya Jl. MT. Haryono 165 Malang, Telp 085251389344

Abstract

This study aims to analyze factors that affect the disclosure of corporate governance and its impact on firm performance. The factors investigated include firm size, listing age, board size, proportion of independent directors and audit committee size. This study used 161 companies listed in Indonesia Stock Exchange by using purposive sampling. The results show that company size, board size, proportion of independent directors, and audit committee size significant affect corporate governance disclosure. Furthermore, this study show that disclosure of corporate governance has significantly positive impact on firm performance as measured by Tobin's $Q$. The firm performance as measured by ROA is not affected by the disclosure of corporate governance.

Keywords: corporate governance, disclosure, firm performance

Abstrak

Penelitian ini bertujuan untuk menganalisis faktor-faktor yang memengaruhi pengungkapan tata kelola perusahaan dan dampaknya terhadap kinerja perusahaan. Faktor-faktornya antara lain, ukuran perusahaan, umur listing, ukuran dewan komisaris, proporsi komisaris independen, dan ukuran komite audit. 
Penelitian ini menggunakan 161 perusahaan yang terdaftar di Bursa Efek Indonesia dengan menggunakan purposive sampling. Hasil penelitian menunjukkan bahwa ukuran perusahaan, ukuran dewan komisaris, proporsi komisaris independen, dan ukuran komite audit berpengaruh terhadap pengungkapan tata kelola perusahaan. Selanjutnya, penelitian ini menunjukkan bahwa pengungkapan tata kelola perusahaan berdampak positif terhadap kinerja perusahaan yang diukur dengan Tobin's Q. Tetapi, kinerja perusahaan yang diukur dengan ROA belum mampu dipengaruhi oleh pengungkapan tata kelola perusahaan.

Kata kunci: tata kelola perusahaan, pengungkapan, kinerja perusahaan

\section{PENDAHULUAN}

Salah satu pengungkapan yang wajib dilaporkan dalam laporan tahunan adalah pengungkapan pelaksanaan tata kelola perusahaan (corporate governance), yang tertuang dalam peraturan Bapepam nomor: KEP-134/BL/2006 tentang kewajiban penyampaian laporan tahunan. Peraturan tersebut memuat item-item minimal yang harus diungkapkan oleh perusahaan berkenaan dengan pelaksanaan tata kelola perusahaan. Pengungkapan yang tidak memadai, tidak dapat meyakinkan para investor bahwa kegiatan pengelolaan perusahaan oleh manajemen dilakukan dengan cara yang bijaksana dan hati-hati untuk kepentingan investor (Cadbury, 1999).

Lemahnya implementasi tata kelola perusahaan akan menyebabkan perusahaan tidak dapat mencapai tujuannya berupa profit yang maksimal, tidak mampu mengembangkan perusahaan dalam persaingan bisnis, dan tidak dapat memenuhi berbagai kepentingan stakeholders (Ruru, 2002). Beberapa kasus yang terkait dengan lemahnya implementasi tata kelola perusahaan dapat memicu perusahaan di dunia mengalami penurunan kinerja, contohnya Union Carbide, Lockheed, Johnson \& Johnson, Enron, Worldcom, dan Xerox (Sulistyanto, 2008:133). Selain itu, kasus korupsi yang kian marak terjadi di Indonesia salah satu penyebabnya adalah implementasi tata kelola pemerintahan yang lemah.

Akibat dari lemahnya penerapan tata kelola perusahaan di Indonesia, pemerintah kemudian membentuk Komite Nasional Kebijakan Corporate Governance (KNKCG) pada tahun 1999 dan berubah nama menjadi Komite Nasional Kebijakan Governance (KNKG) pada tahun 2004. Tahun 2006 KNKG menerbitkan pedoman umum good corporate governance sebagai panduan untuk perusahaan dalam melaksanakan prinsip-prinsip tata kelola perusahaan. Pedoman tersebut berisi tentang asas-asas tata kelola perusahaan, bagaimana pelaksanaan tata kelola di perusahaan, dan siapa saja yang memiliki peranan penting dalam pelaksanaan tata kelola perusahaan.

Kusumawati (2007) berpendapat bahwa investor bersedia membayar premi yang lebih tinggi untuk perusahaan yang menerapkan dan mengungkapkan informasi 
tata kelola perusahaan di dalam laporan tahunan. Pelaksanaan tata kelola perusahaan dan mengungkapkannya dapat memfasilitasi dan meningkatkan kinerja perusahaan, membatasi manajer menyalahgunakan sumber daya perusahaan, dan perilaku oportunistik manajer dapat diawasi (Bhuiyan dan Biswas, 2007).

Penelitian tentang pengungkapan tata kelola perusahaan telah dilakukan di berbagai negara dan berbagai jenis perusahaan, seperti yang dilakukan oleh Haniffa dan Cooke (2002), Bhuiyan dan Biswas (2007), Kusumawati (2007), Mohamad dan Sulong (2010), Nandi dan Ghosh (2012), Samaha, et al. (2012), Natalia dan Zulaikha (2012), dan Barros, Boubaker, dan Hamrouni (2013). Lengkap atau tidaknya pengungkapan tata kelola perusahaan dalam laporan tahunan ternyata dipengaruhi oleh beberapa faktor. Faktor-faktor yang memengaruhi pengungkapan tata kelola perusahaan dalam penelitian ini meliputi, ukuran perusahaan, umur listing, ukuran dewan komisaris, proporsi komisaris independen, dan ukuran komite audit. Pemilihan faktor-faktor ini mengacu pada penelitian sebelumnya yaitu Bhuiyan dan Biswas (2007), dan Samaha, et al. (2012), sehingga dimaksudkan untuk melihat konsistensi hasil penelitian ini dengan penelitian sebelumnya.

Pengungkapan di dalam laporan tahunan merupakan salah satu sinyal yang dapat dipercaya. Pengungkapan yang lengkap dan akurat dapat menjadi penentu peningkatan kinerja perusahaan (Scott, 2009:457). Abdo dan Fisher (2007) berargumen bahwa perusahaan harus memahami pengungkapan tata kelola perusahaan yang diminta oleh publik. Pengungkapan tata kelola perusahaan sangat penting untuk meningkatkan kepercayaan investor terhadap kinerja perusahaan. Implementasi tata kelola perusahaan dan pengungkapannya merupakan hal penting yang harus dilakukan perusahaan agar kebutuhan informasi untuk investor terpenuhi. Pengungkapan tata kelola perusahaan tidak hanya berguna bagi investor saja, tetapi juga bermanfaat bagi perusahaan untuk menarik minat investor agar berinvestasi di perusahaan dan kinerja perusahaan menjadi lebih baik lagi. Oleh karena itu, penelitian ini juga akan menguji pengaruh tata kelola perusahaan terhadap kinerja perusahaan.

Mengingat penerapan tata kelola perusahaan memiliki peranan penting dalam pengelolaan perusahaan dan beberapa penelitian terdahulu memiliki hasil yang beragam, serta tidak sedikit yang tidak membuktikan teori, sehingga penelitian ini penting untuk dilakukan agar memperkuat hasil penelitian yang telah ada dan membuktikan teori yang mendasari penelitian ini. Keseluruhan penelitian ini terinspirasi oleh penelitian Bhuiyan dan Biswas (2007), Abdo dan Fisher (2007), dan Samaha, et al. (2012) dengan melakukan modifikasi dari penelitian sebelumnya.

Perbedaan penelitian ini dengan penelitian sebelumnya yaitu, pertama, penelitian ini tidak hanya menguji faktor-faktor yang mempengaruhi pengungkapan tata kelola perusahaan, tetapi juga mengaitkan dampak pengungkapan tata kelola perusahaan terhadap kinerja perusahaan. Kedua, penelitian ini menggunakan sampel yang lebih besar dibandingkan dengan penelitian sebelumnya. Penelitian ini menggunakan 
sampel 161 perusahaan publik, sedangkan penelitian sebelumnya hanya sebanyak 150 perusahaan publik. Ketiga, penelitian ini menggunakan Tobin's Q dan ROA sebagai pengukuran kinerja perusahaan.

\section{LANDASAN TEORI DAN PENGEMBANGAN HIPOTESIS}

Dasar teori yang digunakan dalam penelitian ini adalah teori agensi level 2 dan signaling theory. Teori agensi menjelaskan hubungan faktor-faktor yang memengaruhi pengungkapan tata kelola perusahaan, sedangkan hubungan pengungkapan tata kelola perusahaan terhadap kinerja perusahaan menggunakan dasar signaling theory. Teori agensi level 2 menjelaskan adanya konflik kepentingan antara pemegang saham mayoritas dan minoritas. Sebagian besar negara di Asia biasanya memiliki kepemilikan terkonsentrasi atau kepemilikan keluarga (Shleifer dan Vishny, 1997). Oleh karena itu, penelitian ini menggunakan teori agensi level 2 karena sesuai dengan kondisi kepemilikan di Indonesia. Signaling theory mengemukakan tentang bagaimana seharusnya sebuah perusahaan memberikan sinyal kepada pengguna laporan tahunan (Jamaan, 2009). Pengungkapan adalah salah satu sinyal yang dapat dipercaya dan mampu menjadi penentu peningkatan kinerja perusahaan. Sinyal yang disampaikan oleh manajer dapat berupa pengungkapan secara lengkap. (Scott, 2009:457).

Pelaksanaan tata kelola yang baik sangat berperan penting untuk menjadikan perusahaan lebih baik lagi. Investor akan menilai tata kelola perusahaan berdasarkan pengungkapan yang dilakukan di dalam laporan tahunan. Pengungkapan tata kelola perusahaan yang disajikan secara lengkap cenderung akan meningkatkan kinerja perusahaan. Ada beberapa faktor yang memengaruhi pengungkapan tata kelola perusahaan, antara lain, ukuran perusahaan, umur listing, ukuran dewan komsaris, proporsi komisaris independen, dan ukuran komite audit. Kelima faktor tersebut akan diuji pengaruhnya terhadap pengungkapan tata kelola perusahaan. Selanjutnya juga akan diuji dampak pengungkapan tata kelola perusahaan terhadap kinerja perusahaan.

\section{Ukuran Perusahaan dan Pengungkapan Tata Kelola Perusahaan}

Ukuran perusahaan menunjukkan besar kecilnya kekayaan (aset) yang dimiliki oleh perusahaan berdasarkan indikator tertentu, diantaranya adalah total aset, log size, nilai saham, jumlah tenaga kerja, penjualan, dan kapitalisasi pasar (Prakoso, 2012). Ukuran perusahaan dianggap penting karena adanya kebutuhan untuk meningkatkan modal dengan biaya terendah, tekanan dari pemegang saham dan analis investasi untuk pengungkapan yang lebih rinci, pengawasan yang lebih rutin oleh otoritas pengawas, kompleksitas struktur bisnis, dan tuntutan yang lebih besar untuk memberikan informasi kepada pemangku kepentingan (Haniffa dan Cooke, 2002). 
Semakin besar ukuran perusahaan, maka kemungkinan hak pemegang saham minoritas dikendalikan oleh pemegang saham mayoritas juga semakin besar. Oleh karena itu, teori agensi memberikan solusi kepada manajer untuk menerapkan tata kelola perusahaan yang baik dan mengungkapkannya di laporan tahunan secara lengkap, luas, dan akurat. Semakin besar ukuran perusahaan, maka semakin luas pengungkapannya tentang tata kelola perusahaan (Sayogo, 2006; Bhuiyan dan Biswas, 2007; Kusumawati, 2007; Benardi 2009; Uyar dan Kilic, 2012; Suta dan Laksito, 2012). Berdasarkan argumentasi teori agensi yang dijelaskan di atas, dapat disimpulkan bahwa ukuran perusahaan berpengaruh positif terhadap pengungkapan tata kelola perusahaan. Oleh karena itu, dirumuskan hipotesis sebagai berikut:

$\mathrm{H}_{1}$ : Ukuran perusahaan berpengaruh positif terhadap pengungkapan tata kelola perusahaan.

\section{Umur Listing dan Pengungkapan Tata Kelola Perusahaan}

Umur listing mencerminkan kemampuan perusahaan bertahan dalam menghadapi persaingan bisnis di pasar modal. Lamanya waktu perusahaan terdaftar di pasar modal mungkin relevan dalam menjelaskan keragaman dalam ketebukaan informasi (Haniffa dan Cooke, 2002). Teori agensi memberikan solusi untuk mengurangi konflik yang terjadi antara pemegang saham mayoritas dan minoritas melalui keterbukaan informasi. Oleh karena itu, perusahaan yang memiliki umur lebih lama dianggap lebih memahami kebutuhan informasi yang diperlukan pemegang saham minoritas, sehingga akan mengungkapkan informasi tata kelola perusahaan secara lengkap, luas, dan akurat, serta hak pemegang saham minoritas tidak terabaikan. Semakin lama perusahaan berada di pasar modal, maka semakin meningkatkan kelengkapan pengungkapan tata kelola perusahaan (Yularto dan Chariri, 2003; Hossain dan Hammami, 2009; Hassan, 2013).

Yularto dan Chariri (2003) melakukan penelitian yang sama. Hasilnya menunjukkan bahwa umur perusahaan berpengaruh terhadap pengungkapan sukarela. Hal itu berarti semakin lama perusahaan terdaftar di pasar modal, maka semakin luas pula pengungkapan yang dilakukan oleh perusahaan. Lamanya umur perusahaan juga mencerminkan kemampuan bertahan dan bersaing di pasar modal. Hassan (2013) berargumen bahwa perusahaan yang lebih lama berada di pasar modal mampu meningkatkan pengungkapan sukarela kepada publik dibandingkan dengan perusahaan yang baru terdaftar. Argumen tersebut dibuktikan dalam penelitiannya yang menunjukkan pengaruh positif antara umur listing dan luas pengungkapan sukarela.

Berdasarkan argumentasi teori agensi yang dijelaskan di atas, disimpulkan bahwa umur listing berpengaruh positif terhadap pengungkapan tata kelola perusahaan. Untuk itu, dirumuskan hipotesis sebagai berikut:

$\mathrm{H}_{2}$ : Umur listing berpengaruh positif terhadap pengungkapan tata kelola perusahaan. 


\section{Ukuran Dewan Komisaris dan Pengungkapan Tata Kelola Perusahaan}

Pedoman umum good corporate governance tahun 2006 menjelaskan bahwa dewan komisaris sebagai organ perusahaan bertugas dan bertanggungjawab secara kolektif untuk melakukan pengawasan dan memberikan nasihat kepada direksi serta memastikan bahwa perusahaan melaksanakan tata kelola perusahaan yang baik. Tetapi, dewan komisaris tidak berhak turut serta dalam mengambil keputusan operasional. Dewan komisaris terdiri dari komisaris independen dan komisaris non independen.

Menurut teori agensi, pemegang saham minoritas akan mengeluarkan biaya lebih untuk mengawasi tindakan manajer dalam mengelola perusahaan, yang disebut dengan biaya agensi. Meminimalisasi biaya agensi diperlukan dewan komisaris yang ditunjuk oleh pemegang saham untuk mengawasi dan memberikan nasihat kepada direksi jika hal tersebut diperlukan, dan memastikan implementasi tata kelola perusahaan terlaksana dengan baik. Keberadaan dewan komisaris di perusahaan, dengan demikian, diharapkan mampu meningkatkan kelengkapan pengungkapan tata kelola perusahaan.

Akhtaruddin, et al. (2009) membuktikan adanya pengaruh antara dewan komisaris terhadap pengungkapan tata kelola perusahaan di dalam penelitiannya. Hal itu berarti bahwa semakin banyak dewan komisaris di perusahaan, maka manajer cenderung akan mengungkapkan informasi tata kelola perusahaan lebih luas dibandingkan dengan perusahaan yang memiliki sedikit dewan komisaris. Penelitian Hassan (2013) menunjukkan bahwa ukuran dewan komisaris berpengaruh terhadap luas pengungkapan sukarela. Adanya dewan komisaris di perusahaan dapat meningkatkan pengungkapan sukarela di perusahaan secara luas, yang semata-mata tidak hanya untuk menaati peraturan saja, tetapi karena timbulnya kesadaran tentang pentingnya keberadaan dewan komisaris untuk mengawasi dewan direksi (Akhtaruddin, et al., 2009; Hassan, 2013; Nandi dan Ghosh, 2012).

Berdasarkan argumentasi tersebut, maka dirumuskan hipotesis sebagai berikut: $\mathrm{H}_{3}$ : Ukuran dewan komisaris berpengaruh positif terhadap pengungkapan tata kelola perusahaan.

\section{Proporsi Komisaris Independen dan Pengungkapan Tata Kelola Perusahaan}

Menurut pedoman umum good corporate governance, komisaris independen adalah komisaris yang tidak terafiliasi dengan perusahaan, tidak memiliki hubungan istimewa dengan anggota direksi atau karyawan perusahaan. Jumlah komisaris independen harus dapat menjamin agar mekanisme pengawasan berjalan secara efektif dan sesuai dengan peraturan perundang-undangan.

Penunjukkan komisaris independen dimaksudkan untuk mewakili pemegang saham dalam hal mengawasi tindakan manajer dalam mengelola perusahaan dan 
mendorong manajer untuk mengungkapkan informasi perusahaan, termasuk mengenai pelaksanaan tata kelola perusahaan secara lengkap. Komisaris independen merupakan pihak luar yang tidak terafiliasi dengan perusahaan, maka keberadaan komisaris independen di perusahaan diharapkan mampu meningkatkan pengungkapan tata kelola perusahaan.

Keberadaan komisaris independen mampu menunjang pengungkapan tata kelola perusahaan yang lebih luas. Semakin besar jumlah komisaris independen di perusahaan, maka semakin luas informasi tata kelola perusahaan yang diungkapkan (Eng dan Mak, 2003; Cheng dan Courtenay, 2006; Akhtaruddin, et al., 2009; Samaha, et al., 2012; Barros, et al., 2013; Janadi, Rahman dan Omar, 2013).

Berdasarkan argumentasi tersebut maka, dirumuskan hipotesis sebagai berikut:

$\mathrm{H}_{4}$ : Proporsi komisaris independen berpengaruh positif terhadap pengungkapan tata kelola perusahaan.

\section{Ukuran Komite Audit dan Pengungkapan Tata Kelola Perusahaan}

Keputusan ketua Bapepam No.Kep-29/PM/2004 tentang pembentukan dan pedoman pelaksanaan kerja komite audit menyatakan bahwa komite audit adalah komite yang dibentuk oleh dewan komisaris. Komite audit berperan dalam membantu melaksanakan tugas dan fungsi komisaris untuk mengawasi tindakan manajer sebagai upaya mengurangi biaya agensi. Adanya komite audit di perusahaan juga dapat membantu meningkatkan kualitas pengungkapan tata kelola perusahaan yang lebih lengkap.

Semakin banyak komite audit independen yang dimiliki oleh perusahaan, maka semakin luas pula pengungkapan tata kelola perusahaan yang dilakukan. Dengan kata lain, adanya komite audit di perusahaan dapat meningkatkan transparansi dan pengungkapan tata kelola perusahaan yang lebih luas, lengkap, dan akurat (Barako, et al., 2006; Kusumawati, 2007; Bhayani, 2012; Natalia dan Zulaikha, 2012; Samaha, et.al., 2012; Barros, et al., 2013).

Berdasarkan argumentasi tersebut, maka dirumuskan hipotesis sebagai berikut:

$\mathrm{H}_{5}$ : Ukuran komite Audit berpengaruh positif terhadap pengungkapan tata kelola perusahaan.

\section{Pengungkapan Tata Kelola Perusahaan dan Kinerja Perusahaan}

Signaling theory mengemukakan tentang bagaimana seharusnya sebuah perusahaan memberikan sinyal kepada pemegang saham (Jamaan, 2009). Scott (2009:457) menjelaskan bahwa sinyal yang disampaikan oleh manajer dapat berupa pengungkapan secara lengkap di laporan tahunan. Pengungkapan yang secara lengkap dapat menjadi penentu peningkatan kinerja perusahaan. Selain itu. jika kesenjangan informasi dan biaya agensi dapat dikurangi dengan melakukan 
pengungkapan tata kelola perusahaan, maka investor akan menilai perusahaan tersebut memiliki kinerja yang baik.

Pengungkapan tata kelola perusahaan berpengaruh terhadap kinerja perusahaan (Abdo dan Fisher, 2007). Semakin luas pengungkapan tata kelola perusahaan yang dilakukan, maka kinerja perusahaan akan semakin meningkat (Abdo dan Fisher, 2007; Bhagat dan Bolton, 2008; Darwis, 2009). Perusahaan yang mengimplementasikan tata kelola perusahaan yang baik dan mengungkapkannya di laporan tahunan secara lengkap akan menarik investor untuk berinvestasi di perusahaan dan akan meningkatkan kinerja perusahaan. Ammann, Oesch, dan Schimid (2013) mengukur kinerja perusahaan menggunakan Tobin's $Q$ dan mendapatkan bukti bahwa Tobin's Q mampu ditingkatkan dengan mengungkapkan tata kelola perusahaan yang lebih lengkap. Munisi dan Randoy (2013) mengukur kinerja perusahaan dari sisi keuangannya yaitu menggunakan ROA. Perusahaan yang setuju dengan penerapan tata kelola perusahaan dapat diperkirakan mencapai kinerja keuangan yang lebih tinggi dan mengurangi biaya agensi (Munisi dan Randoy, 2013).

Berdasarkan argumentasi signaling theory yang dijelaskan di atas, dapat disimpulkan bahwa pengungkapan tata kelola perusahaan berpengaruh positif terhadap kinerja perusahaan. Maka dari itu, dirumuskan hipotesis sebagai berikut: $\mathrm{H}_{6 \mathrm{a}}$ : Pengungkapan tata kelola perusahaan berpengaruh positif terhadap Tobin's Q.

$\mathrm{H}_{6 \mathrm{~b}}$ : Pengungkapan tata kelola perusahaan berpengaruh positif terhadap ROA.

\section{METODE PENELITIAN}

\section{Populasi dan Sampel}

Populasi penelitian ini adalah seluruh perusahaan yang terdaftar di Bursa Efek Indonesia (BEI) periode 2009-2012. Jumlah populasi sampai dengan tahun 2013 adalah sebanyak 473 perusahaan publik. Penentuan sampel ditentukan dengan menggunakan purposive sampling dan diperoleh sampel sebanyak 161 perusahaan. Kriteria yang digunakan untuk pemilihan sampel yaitu:

1. Perusahaan yang terdaftar di Bursa Efek Indonesia selama periode 20092012, karena periode tersebut merupakan tahun pengamatan yang dilakukan peneliti. Perusahaan yang tidak terdaftar pada periode tersebut tidak dapat dijadikan sebagai sampel.

2. Tersedianya laporan tahunan selama tahun 2009-2011 secara berturut-turut, karena peneliti menggunakan data penelitian yang diambil dari laporan tahunan pada periode tersebut. Perusahaan yang laporan tahunannya tidak tersedia secara berturut-turut tidak dapat dijadikan sebagai sampel.

3. Tersedianya data saham selama tahun 2009-2012 secara berturut-turut, karena peneliti menggunakan data saham per 31 Maret 2009-2012. Dipilihnya periode 31 Maret karena pada tanggal tersebut laporan tahunan perusahaan dipublikasikan. 
4. Perusahaan yang mengungkapkan pelaksanaan tata kelola perusahaan dalam laporan tahunan selama periode pengamatan.

\section{Definisi dan Pengukuran Variabel}

Definisi dan pengukuran masing-masing variabel yaitu:

Pengungkapan Tata Kelola Perusahaan. Metode yang digunakan untuk membuat indeks adalah nilai dikotomis, yaitu nilai 1 untuk item yang diungkapkan dan nilai 0 untuk item yang tidak diungkapkan. Jenis item-item yang digunakan dalam penelitian ini secara umum merujuk pada Keputusan Ketua Bapepam-LK No.Kep134/BL/2006 dan dilengkapi dengan pedoman umum tata kelola perusahaan dari Komite Nasional Kebijakan Governance (KNKG) tahun 2006. Perhitungan indeks pengungkapan diukur dengan cara sebagai berikut (Natalia dan Zulaikha, 2012): $\Sigma$ item pengungkapan yang diperoleh perusahaan

Indeks Pengungkapan $=-\times 100$ $\Sigma$ item yang mungkin diperoleh perusahaan

\section{Kinerja Perusahaan}

Kinerja perusahaan merupakan gambaran pencapaian pelaksanaan kegiatan perusahaan dalam mewujudkan sasaran, tujuan, visi dan misi organisasi. Kinerja perusahaan dapat diukur dengan menghitung kinerja pasarnya atau kinerja keuangannya, dalam penelitian ini menggunakan kedua perhitungan tersebut, yaitu:

a. Tobin's Q, merupakan pengukuran kinerja pasar perusahaan. Tobin's Q dipilih karena diyakini memberikan gambaran mengenai penilaian pasar terhadap perusahaan, tidak hanya dari aspek fundamental perusahaan, tetapi juga dari berbagai aspek yang dilihat oleh pihak luar (Hastuti, 2005).

Perhitungan Tobin's Q $=\underline{\text { MVE + total kewajiban }}$

Total Aset

\section{Keterangan:}

MVE

: Rata-rata harga penutupan saham x banyaknya saham biasa yang beredar

Total kewajiban $\quad$ : Kewajiban Lancar + Kewajiban Tidak Lancar

b. ROA, merupakan pengukuran kinerja keuangan perusahaan. ROA dipilih karena merupakan pengukuran efisiensi perusahaan dalam menghasilkan keuntungan dengan memanfaatkan aset yang dimiliki (Prakoso, 2012).

Perhitungan ROA = Laba bersih

Total Aset

Ukuran Perusahaan, menunjukkan besar kecilnya kekayaan yang dimiliki oleh perusahaan. Penggunaan logaritma natural $(\ln )$ ini dilakukan karena untuk 
menghindari fluktuasi data berlebih. Rumus menghitung ukuran perusahaan sebagai berikut (Benardi, 2009; Prakoso, 2012):

Ukuran perusahaan $=L n$ total Aset.

Umur Listing, merupakan lamanya perusahaan berada di pasar modal dan mencerminkan kemampuan perusahaan bertahan di tengah persaingan bisnis. Diukur menggunakan selisih tahun pada laporan tahunan dengan tahun perusahaan pada saat terdaftar di Bursa Efek Indonesia (Bhuiyan dan Biswas, 2007; Hossain dan Hammami, 2009).

Umur Listing $=$ Tahun pada laporan tahunan - Tahun perusahaan

$$
\text { terdaftar di BEI }
$$

Ukuran Dewan Komisaris, merupakan jumlah anggota komisaris independen dan komisaris non independen suatu perusahaan. Diukur dengan menjumlah keseluruhan anggota dewan komisaris (Bhuiyan dan Biswas, 2007; Samaha, et al., 2012). Ukuran dewan komisaris $=\Sigma$ Anggota dewan komisaris keseluruhan

Proporsi Komisaris Independen, adalah anggota dewan komisaris yang tidak terafiliasi dengan perusahaan. Diukur dengan membandingkan antara jumlah komisaris independen dengan jumlah keseluruhan dewan komisaris (Mohamad dan Sulong, 2010; Samaha, et al, 2012).

Proporsi komisaris independen $=\underline{\Sigma \text { Anggota komisaris independen }} \times 100$ $\Sigma$ Anggota dewan komisaris

Ukuran Komite Audit, adalah komite yang bekerja secara profesional dan independen yang dibentuk oleh dewan komisaris. Menghitung anggota komite audit independen yaitu dengan menjumlah keseluruhan anggota komite audit (Kumaat, 2013).

Ukuran komite audit $=\Sigma$ Anggota komite audit keseluruhan

\section{Teknik Analisis data}

Teknik analisis data yang digunakan dalam penelitian ini adalah analisis kuantitatif dengan menggunakan regresi linear. Penggunaan regresi linear bertujuan untuk memprediksi variabel dependen di masa datang. Penelitian Benardi (2008) melakukan pengujian melalui dua tahap dengan bentuk persamaan yang berbeda. Oleh karena itu, penelitian ini juga melakukan pengujian melalui dua tahap dan menggunakan persamaan secara terpisah. Model analisis dapat dirumuskan dalam bentuk persamaan sebagai berikut:

Indeks Pengungkapan $=\beta_{0}+\beta_{1} \mathrm{UP}+\beta_{2} \mathrm{UL}+\beta_{3} \mathrm{UDK}+\beta_{4} \mathrm{KI}+\beta_{5} \mathrm{UKA}+\mathrm{e}($ Model 1$)$ Kinerja Perusahaan $=\beta_{0}+\beta_{1}$ Indeks Pengungkapan $+\mathrm{e}$

(Model 2) 


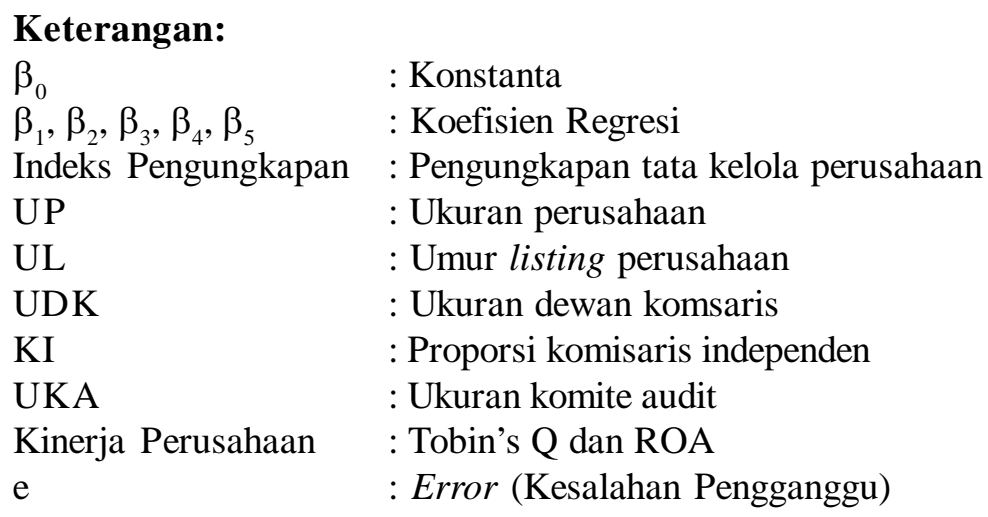

\section{HASIL PENELITIAN DAN PEMBAHASAN}

Peraturan Bapepam nomor KEP-134/BL/2006 berisi item-item minimal yang wajib diungkapkan oleh perusahaan. Item-itemnya antara lain mengenai informasi dewan komisaris, dewan direksi, komite audit, dan komite-komite yang dibentuk oleh dewan komisaris, sekretaris perusahaan, sistem pengendalian internal, risiko perusahaan, aktivitas dan biaya sosial, perkara yang dihadapi perusahaan, profil perusahaan, transaksi yang memiliki benturan kepentingan dan hasil penilaian tata kelola perusahaan yang dilaporkan dalam RUPS.

\section{Hasil Pengujian Hipotesis}

Hasil pengujian hipotesis ini telah memenuhi persyaratan uji asumsi klasik. Hasil regresi model 1 dan model 2 dapat dilihat pada tabel 1. Berdasarkan tabel 1, adjusted $\mathrm{R}^{2}$ model 1 adalah 0,467 yang artinya sebesar $46,7 \%$ variasi dari pengungkapan tata kelola perusahaan dapat dijelaskan oleh kelima variabel independen dalam model regresi pertama. Sisanya sebesar 53,3\% dijelaskan oleh variabel lain yang tidak termasuk dalam model regresi pertama ini. Nilai $\mathrm{R}^{2}$ model 2 Tobin's Q sebesar 0,184 atau 18,4\%. Artinya bahwa 18,4\% keragaman kinerja perusahaan yang diukur dengan Tobin's $Q$ dipengaruhi oleh variabel independen indeks pengungkapan. Sisanya sebesar 81,6\% dijelaskan oleh variabel lain di luar variabel yang diteliti. Keragaman ROA hanya dipengaruhi oleh $0,7 \%$ variabel indeks pengungkapan yang ditunjukkan oleh nilai $\mathrm{R}^{2}$ sebesar 0,007 . Sisanya sebesar $99,3 \%$ dipengaruhi oleh variabel lain diluar variabel yang diteliti. Nilai adjusted $\mathrm{R}^{2}$ dan $\mathrm{R}^{2}$ yang rendah dalam penelitian ini tetap dapat memenuhi tujuan penelitian, karena penelitian ini menguji hubungan pengaruhnya dan bukan menguji besar pengaruhnya antar variabel penelitian. 
Tabel 1. Hasil Pengujian Hipotesis

\begin{tabular}{cccc}
\hline Variabel & Model 1 & \multicolumn{3}{c}{ Model 2 } & ROA \\
\cline { 2 - 4 } (constant) & $-0,107$ & Tobin's Q & $-3,056$ \\
& $(-2,183)^{* * *}$ & $(10,624)^{* * *}$ & $(-19,744)^{* * * *}$ \\
UP & 0,015 & - & - \\
& $(7,577)^{* * *}$ & - & - \\
UL & $-0,001$ & - & - \\
& $(-0,895)$ & - & - \\
UDK & 0,017 & - & - \\
& $(4,937)^{* * *}$ & - & - \\
KI & 0,161 & - & - \\
& $(4,769)^{* * *}$ & - & - \\
UKA & 0,059 & - & - \\
IP & $(9,061)^{* * *}$ & - & $-0,623$ \\
& - & 0,713 & $(-1,871)^{* *}$ \\
Adjusted R & - & $(9,965)^{* * *}$ & 0,007 \\
$\mathrm{R}^{2}$ & 0,467 & & \\
\hline
\end{tabular}

***signifikan pada $\alpha=1 \%$, **signifikan pada $\alpha=5 \%$, *signifikan pada $\alpha=10 \%$

Berdasarkan tabel 1 di atas, dapat disimpulkan bahwa ukuran perusahaan berpengaruh secara positif terhadap pengungkapan tata kelola perusahaan $(t=7,577$, $\alpha=0,000)$, sehingga hipotesis pertama $\left(\mathrm{H}_{1}\right)$ diterima. Umur listing tidak memiliki pengaruh positif terhadap pengungkapan tata kelola perusahaan $(\mathrm{t}=-0,895, \alpha=0,371)$. Oleh karena itu, hipotesis kedua $\left(\mathrm{H}_{2}\right)$ ditolak. Ukuran dewan komisaris (UDK) berpengaruh secara positif terhadap pengungkapan tata kelola perusahaan $(t=4,937$, $\alpha=0,000)$, sehingga hipotesis ketiga $\left(\mathrm{H}_{3}\right)$ dalam penelitian ini diterima. Tabel 1 juga menunjukkan bahwa proporsi komisaris independen (KI) berpengaruh secara positif terhadap pengungkapan tata kelola perusahaan $(t=4,769, \alpha=0,000)$, sehingga hipotesis keempat $\left(\mathrm{H}_{4}\right)$ dalam penelitian ini diterima. Begitu juga dengan ukuran komite audit berpengaruh positif terhadap pengungkapan tata kelola perusahaan $(\mathrm{t}=9,061$, $\alpha=0,000)$. Oleh karena itu, Hipotesis kelima $\left(\mathrm{H}_{5}\right)$ dalam penelitian ini diterima.

Ditunjukkan oleh tabel 1, pengungkapan tata kelola perusahaan memiliki pengaruh terhadap kinerja perusahaan yang diukur menggunakan Tobin's $Q(t=9,965$, $\alpha=0,000)$, sehingga hipotesis keenam $\left(\mathrm{H}_{6 \mathrm{a}}\right)$ diterima. Berdasarkan tabel 1 di atas, jika menggunakan tingkat signifikansi $\alpha$ sebesar 0,01 dan 0,05 maka variabel indeks pengungkapan tidak memiliki pengaruh terhadap ROA. Namun, jika menggunakan signifikansi $\alpha$ sebesar 0,10 maka indeks pengungkapan berpengaruh terhadap ROA, karena nilai signifikansinya kurang dari $0,10(0,062<0,10)$. Tetapi arah pengaruhnya bernilai negatif $(\mathrm{t}=-0,623, \alpha=0,062)$, sehingga hipotesis keenam $\left(\mathrm{H}_{6 \mathrm{~b}}\right)$ ditolak. 


\section{Diskusi Hasil Penelitian}

Semakin besar ukuran perusahaan maka akan meningkatkan kelengkapan pengungkapan tata kelola perusahaan. Secara teoritis, perusahaan yang berukuran besar memiliki biaya agensi yang lebih besar pula (Benardi, 2009), sehingga perusahaan akan mengungkapkan informasi tata kelola yang lebih lengkap. Hasil penelitian ini konsisten dengan penelitian Bhuiyan dan Biswas (2007), Kusumawati (2007), Benardi (2009), dan Uyar dan Kilic (2012). Hal ini dapat menjelaskan bahwa perusahaan yang total asetnya besar memiliki kepercayaan diri bahwa perusahaan telah dikelola dengan baik, dilihat dari semakin lengkapnya pengungkapan tata kelola perusahaan di laporan tahunan. Ukuran perusahaan merupakan faktor yang penting dari pengungkapan informasi, perusahaan yang lebih besar memberikan informasi lebih banyak daripada perusahaan yang lebih kecil (Uyar dan Kilic, 2012).

Umur listing tidak berpengaruh terhadap pengungkapan tata kelola perusahaan. Dengan kata lain, lamanya umur perusahaan terdaftar di pasar modal tidak menjamin pengungkapan tata kelola perusahaan juga akan meningkat. Penelitian ini konsisten dengan penelitian Haniffa dan Cooke (2002), Suta dan Laksito (2012), dan Galani, et al. (2012). Ada beberapa hal yang mendasari perusahaan yang baru terdaftar untuk mengungkapkan laporan tata kelola perusahaan, diantaranya yaitu teknologi yang semakin canggih, penambahan modal dengan biaya rendah, dan meningkatkan kepercayaan. Suta dan Laksito (2012) beranggapan bahwa perusahaan yang baru atau yang telah lama terdaftar di pasar modal sama-sama ingin menarik perhatian investor untuk berinvestasi di perusahaan. Perusahaan akan berusaha mengungkapkan informasi tata kelola perusahaan secara lengkap demi kebutuhan investor.

Ukuran dewan komisaris memiliki pengaruh terhadap pengungkapan tata kelola perusahaan. Artinya, adanya dewan komisaris di perusahaan mampu meningkatkan pengungkapan tata kelola perusahaan di laporan tahunan. Hasil penelitian ini mendukung penelitian Akhtaruddin, et al. (2009), Nandi dan Ghosh (2012), dan Hassan (2013). Dewan komisaris yang memiliki keahlian dan kompetensi untuk melaksanakan tugas dan kewajibannya mampu mendorong pihak manajemen untuk menerapkan pengungkapan tata kelola perusahaan dan mengungkapkannya secara lengkap di laporan tahunan. Teori agensi menjelaskan bahwa pemegang saham minoritas akan mengeluarkan biaya lebih untuk mengawasi tindakan manajer dalam mengelola perusahaan, yang disebut dengan biaya agensi. Untuk meminimalisir biaya agensi, diperlukan dewan komisaris yang ditunjuk oleh pemegang saham. Jumlah dewan komisaris yang besar mampu menyediakan informasi tata kelola perusahaan secara lengkap kepada pemegang saham (Akhtaruddin, et al., 2009).

Proporsi komisaris independen juga berpengaruh terhadap pengungkapan tata kelola perusahaan. Artinya, peningkatan proporsi komisaris independen di perusahaan dapat meningkatkan kelengkapan informasi tata kelola perusahaan di laporan tahunan. Hasil penelitian ini mendukung penelitian Eng dan Mak (2003), Cheng dan 
Courtenay (2006), Akhtaruddin, et al. (2009), Samaha, et al. (2012), Barros, et al. (2013), Janadi, et al. (2013). Komisaris independen dipilih untuk mewakili pemegang saham dalam mengawasi tindakan manajemen di perusahaan. Penelitian ini memberikan bukti bahwa komisaris independen memang mampu mewakili pemegang saham minoritas agar manajemen memberikan pengungkapan yang secara lengkap, sehingga biaya agensi yang ditanggung oleh pemegang saham minoritas dapat dikurangi. Barros, et al. (2013) mengatakan bahwa keberadaan komisaris independen menjadi bagian terpenting sejak komisaris independen menyumbangkan pengalamannya untuk perusahaan dan melindungi seluruh kepentingan dari perilaku oportunistik yang hanya memperkecil keuntungan pemegang saham.

Ukuran komite audit berpengaruh terhadap pengungkapan tata kelola perusahaan. Artinya, adanya komite audit di perusahaan dapat meningkatkan kualitas dan kelengkapan informasi tata kelola perusahaan di laporan tahunan. Komite audit bertugas untuk membantu tugas-tugas dewan komisaris dalam hal mengawasi tindakan manajer. Terbukti dari penelitian ini, komite audit efektif untuk meningkatkan kualitas pengungkapan tata kelola perusahaan di laporan tahunan. Hasil ini sejalan dengan penelitian Kusumawati (2007), Bhayani (2012), Samaha, et al. (2012), Natalia dan Zulaikha (2012), dan Barros, et al. (2013). Samaha, et al. (2012) berpendapat bahwa keberadaan komite audit untuk melengkapi peran pengawasan agar mengungkapkan informasi tata kelola perusahaan.

Pengungkapan tata kelola perusahaan memiliki pengaruh terhadap kinerja perusahaan yang diukur menggunakan Tobin's Q. Hasil penelitian ini memberikan bukti bahwa kinerja pasar perusahaan dapat ditingkatkan dengan mengungkapkan informasi tata kelola perusahaan secara lengkap di laporan tahunan. Hal ini menunjukkan bahwa investor memberikan penilaian yang baik kepada perusahaan jika mengungkapkan tata kelola perusahaan. Penilaian baik dari investor akan semakin meningkat seiring dengan peningkatan pengungkapan tata kelola perusahaan oleh pihak manajemen. Hasil ini konsisten dengan penelitiannya Abdo dan Fisher (2007), Ammann, et al. (2013), dan Chen, et al. (2013). Penelitian ini telah membuktikan signaling theory yang menyatakan bahwa pengungkapan merupakan sinyal yang dapat dipercaya dan mampu menjadi penentu peningkatan kinerja perusahaan (Scott, 2009:457).

Pengungkapan tata kelola perusahaan tidak memiliki pengaruh positif terhadap kinerja perusahaan yang diukur menggunakan ROA. Artinya, setiap peningkatan pengungkapan tata kelola perusahaan belum mampu meningkatkan kinerja keuangan perusahaan. Secara teoritis, pengungkapan merupakan sinyal yang dapat dipercaya dan mampu menjadi penentu peningkatan kinerja perusahaan (Scott, 2009:457). Tetapi, hasil penelitian ini tidak dapat membuktikan teori tersebut. Diketahui bahwa kinerja keuangan perusahaan tidak dapat ditingkatkan dengan pengungkapan tata kelola perusahaan di laporan tahunan. Hal ini dikarenakan pengungkapan tata kelola merupakan pengungkapan perusahaan yang tergolong non keuangan, sedangkan 
ROA dihitung berdasarkan sisi keuangannya saja. Di samping itu, ROA merupakan cerminan kemampuan perusahaan dalam menghasilkan laba dari total aset yang dipergunakan untuk kegiatan operasional. Laba yang dihasilkan perusahaan tidak tergantung pada seberapa lengkap informasi tata kelola perusahaan, melainkan tergantung pada seberapa banyak pelanggan yang membeli barang atau jasa perusahaan.

Hasil ini di luar prediksi, karena beberapa penelitian terdahulu menunjukkan hasil yang positif, di antaranya Klapper dan Love (2004), Chiang (2005), Bhagat dan Bolton (2008), dan Munisi dan Randoy (2013). Tetapi hasil penelitian ini sesuai dengan penelitiannya Suyanto (2007). Menurut Suyanto (2007) tidak berpengaruhnya keterbukaan informasi terhadap ROA akibat dari rendahnya tingkat utilitas aset (produktivitas) dan efisiensi, karena dua hal ini berkaitan langsung dengan tinggi rendahnya ROA.

\section{SIMPULAN}

Penelitian ini bertujuan untuk membuktikan bahwa kinerja perusahaan dapat ditingkatkan dengan memperluas dan melengkapi pengungkapan tata kelola perusahaan, serta mengidentifikasi faktor-faktor apa saja yang dapat meningkatkan pengungkapan tata kelola perusahaan. Hasil analisis menunjukkan bahwa ukuran perusahaan, ukuran dewan komisaris, komisaris independen, dan komite audit dapat meningkatkan pengungkapan tata kelola perusahaan, kecuali umur listing. Begitu juga dengan kinerja perusahaan, pasar akan menilai perusahaan memiliki kinerja yang baik jika mengungkapkan informasi tata kelola perusahaan secara lengkap.

Pengungkapan yang diberikan oleh perusahaan secara lengkap, luas, dan akurat dapat meningkatkan kinerja perusahaan. Pasar akan menilai perusahaan memiliki kinerja yang baik, jika kebutuhan informasi yang diperlukan oleh investor dapat terpenuhi. Sebaliknya, jika informasi yang diperlukan oleh investor tidak memadai, maka kinerja perusahaan dinilai kurang baik. Perusahaan yang memiliki kinerja baik akan mendapatkan perhatian lebih dari investor untuk berinvestasi di perusahaan. Oleh karena itu, meningkatkan pengungkapan tata kelola perusahaan salah satu alternatif untuk meningkatkan kinerja perusahaan.

Penelitian ini memberikan kontribusi di antaranya yaitu pertama, hasil penelitian ini mampu menjelaskan dan membuktikan solusi yang diberikan teori agensi untuk menerapkan tata kelola yang baik, agar asimetri informasi dan biaya agensi dapat dikurangi. Hasil penelitian ini juga mampu membuktikan signaling theory yang menekankan bahwa pengungkapan dapat meningkatkan kinerja perusahaan. Kedua, hasil penelitian ini mendapati temuan baru bahwa kinerja perusahaan yang dilihat dari sisi keuangannya tidak memiliki keterkaitan dengan pengungkapan tata kelola perusahaan. Ketiga, penelitian ini memberikan bukti bahwa penerapan tata kelola perusahaan dan pengungkapannya berperan penting dalam peningkatan kinerja perusahaan. 
Keterbatasan dalam penelitian ini yaitu pertama, penilaian pengungkapan tata kelola perusahaan cenderung bersifat subyektif. Kedua, sampel yang diperoleh hanya 161 perusahaan saja dari 473 perusahaan yang tercatat di BEI. Peneliti tidak menemukan atau tidak tersedianya laporan tahunan di situs BEI ataupun di situs perusahaan yang bersangkutan. Ketiga, penelitian ini tidak menguji pengungkapan tata kelola perusahaan selain yang disajikan di laporan tahunan.

Berdasarkan keterbatasan tersebut, maka saran untuk penelitian selanjutnya yaitu pertama, dapat mengatasi masalah subyektifitas dalam penilaian pengungkapan tata kelola perusahaan dengan mempertimbangkan sudut pandang atau interpretasi dari pihak lain. Kedua, diharapkan memperluas jumlah sampel, dimaksudkan untuk melihat kekonsistenan hasil dan dapat dijadikan sebagai pembanding dengan penelitian ini. Ketiga, menguji pengungkapan tata kelola perusahaan selain yang disajikan di laporan tahunan, seperti pengungkapan tata kelola perusahaan di website perusahaan.

\section{DAFTAR PUSTAKA}

Abdo, A., dan Fisher, G. 2007. The Impact of Reported Corporate Governance Disclosure on the Financial Performance of Companies Listed on the JSE. Investment Analysts Journal. No. 66.

Akhtaruddin, M., Hossain, M.A., Hossain, M. dan Yao, L. 2009. Corporate Governance and Voluntary Disclosure in Corporate Annual Reports of Malaysian Listed Firms. JAMAR. Vol.7, No. 1.

Ammann, M., Oesch, D., dan Schmid, M.M. 2013. Product Market Competition, Corporate Governance, and Firm Value: Evidance from the EU-Area. European Financial Management. Vol 19. No3. Hal 452-469.

Bapepam-LK. 2006. Keputusan Ketua Bapepam-LK No.KEP-134/BL/2006 Tentang Kewajiban Penyampaian Laporan Tahunan bagi Emiten atau Perusahaan Publik, http://www.bapepam-lk.go.id. Diakses tanggal 3 Maret 2013. . 2004. Keputusan Ketuan Bapepam No.KEP-29/PM/2004 Tentang Pembentukan Dan Pedoman Pelaksanaan Kerja Komite Audit, http://www.bapepam-lk.go.id. Diakses tanggal 3 Maret 2013.

Barros, C.P., Boubaker, S., dan Hamrouni, A. 2013. Corporate Governance And Voluntary Disclosure In France. The Journal of Applied Business Research. Vol 29. No 2.

Benardi, M.K. 2009. Faktor-Faktor yang Mempengaruhi Luas Pengungkapan dan Implikasinya Terhadap Asimetri Informasi (Studi Pada Perusahaan-Perusahaan Sektor Manufaktur yang Go Public di Bursa Efek Indonesia), Tesis, Program Magister Akuntansi, Universitas Brawijaya.

Bhagat, S. dan Bolton, B. 2008. Corporate Governance dan Firm Performance. Journal of Corporate Finance 14:257-273.

Bhayani, S. 2012. Association Between Firm-Spesific Characteristics and Corporate Disclosure: The Case Of India. Prosiding International Conference on Business, Economics, Management and Behavioral Sciences Dubai. 
Bhuiyan, M.H.U., dan Biswas, P.K. 2007. Corporate Governance And Reporting: An Empirical Study Of The Listed Companies In Bangladesh. Journal Of Business Studies. Vol. XXVIII No.1.

Cadbury, S.A. 1999. Corporate Governance: A Framework For Implementation-Overview, http://www.sovereignglobal.com. Diakses tanggal 7 Maret 2013.

Chen, J.J., Cheng, X., Gong, S.X., dan Tan, Y. 2013. Do Higher Value Firms Voluntarily Disclose More Information? Evidence From China. The British Accounting Review.

Cheng, E.C.M., dan Courtenay, S.M. 2006. Board Composition, Regulatory Regime, and Voluntary Disclosure. International Journal of Accounting 41:262-289.

Chiang, H. 2005. An Empirical Study of Corporate Governance and Corporate Performance. Journal of American Academy of Business. Vol.6. No.1. Hal.95-101.

Darwis, H. 2009. Corporate Governance Terhadap Kinerja Perusahaan. Jurnal Keuangan dan Perbankan. Vol.13, No.3 p.418-430.

Eng, L.L., dan Mak, Y.T. 2003. Corporate Governance and Voluntary Disclosure. Journal of Accounting and Public Policy 22. Hal.325-345.

Galani, D., Alexandridis, A., dan Stavropoulos, A. 2011. The Association Between the Firm Characteristics and Corporate Mandatory Disclosure: The case Of Greece. World Academy of Sciences, Engineering and Technology 53.

Haniffa, R.M., dan T.E. Cooke. 2002. Culture, Corporate Governance and Disclosure in Malaysian Corporation. ABACUS. Vol.38. No.3. Hal. 317-349.

Hassan, M.K. 2013. Corporate Governance Characteristics and Voluntary Disclosure: The Case of UAE Listed Corporations. Prosiding International Conference on Business, Economics, and Accounting, Bangkok.

Hastuti, T.D. 2005. Hubungan Antara Good Corporate Governance dan Struktur Kepemilikan Dengan Kinerja Keuangan. Prosiding Simposium Nasional Akuntansi VIII Solo.

Hossain, M. dan Hammami, H. 2009. Voluntary Disclosure in the Annual reports of an Emerging Country: The Case Of Qatar. Advances in Accounting, Incorporating Advances in International Accounting 25:255-265.

Jama'an. 2008. Pengaruh Mekanisme Corporate Governance, dan Kualitas Kantor Akuntan Publik Terhadap Integritas Informasi Laporan Keuangan, Tesis, Program Magister Sains Akuntansi, Universitas Diponegoro.

Janadi, Y., Rahman, R.A., dan Omar, N.H. 2013. Corporate Governance Mechanism and Voluntary Disclosure in Saudi Arabia. Research Journal of Finance and Accounting. Vol.4 No.4

Klapper, L.F. dan Love, I. 2004. Corporate Governance, Investor Protection, and Performa in Emerging Markets. Journal Of Corporate Finance 10:703-728.

Komite Nasional Kebijakan Governance (KNKG). 2006. Pedoman Umum Good Corporate Governance Indonesia, http://www.bapepam.go.id. Diakses tanggal 3 Maret 2013.

Kumaat, L.C. 2013. Pengaruh Corporate Governance dan Struktur Kepemilikan Terhadap Manajemen Laba dan Kinerja Perusahaan, Tesis, Program Magister Akuntansi, Universitas Brawijaya.

Kusumawati, D.N. 2007. Profitability And Corporate Governance Disclosure: An Indonesian Study. Jurnal Riset Akuntansi Indonesia. Vol.10. No.2. hal. 131-146. 
Mohamad, W.I.A.W., dan Sulong, Z. 2010. Corporate Governance Mechanisms And Extent Of Disclosure: Evidence From Listed Companies In Malaysia. International Business Research. Vol.3. No.4.

Munisi, G., dan Randoy, T. 2013. Corporate Governance and Company Performance Across Sub-Saharan African Countries. Journal of Economics and Business. Vol 70 hal.92110.

Nandi, S., dan Ghosh, S.K. 2012. Corporate Governance Attributes, Firm Characteristics and The Level of Corporate Disclosure: Evidance From The Indian Listed Firms. Decision Science Letters 2:45-58.

Natalia, P., dan Zulaikha. 2012. Analisis Faktor-Faktor Yang Mempengaruhi Pengungkapan Corporate Governance Pada Laporan Tahunan. Diponegoro Journal Of Accounting. Vol.1. No.2.

Prakoso, R.Y. 2012. Pengaruh Karakteristik Perusahaan Terhadap Luas Pengungkapan Corporate Social Responsibility dan Dampaknya Terhadap Nilai Perusahaan, Tesis, Program Magister Akuntansi, Universitas Brawijaya.

Ruru, B. 2002. Penerapan Prinsip-Prinsip Good Corporate Governance Di Lingkungan BUMN, http://www.bumn.go.id. Diakses tanggal 5 Februari 2013.

Samaha, K., Dahawy, K., Hussainey, K., dan Stapleton, P. 2012. The Extent Of Corporate Governance Disclosure And Its Determinants In A developing Market: The Case Of Egypt. Advances In Accounting 28 (1):168-178.

Sammari, B., dan Sultan, W. 2010. Corporate Governance and Voluntary Disclosure in Kuwait. International Journal of Disclosure and Governance. Vol.7. No.3. hal.262280.

Sayogo, D.S. 2006. The Determinan Of Corporate Governance Disclosure Through Internet For Companies Listing In Jakarta Stock Exchange. Prosiding Simposium Nasional Akuntansi IX Padang.

Sugiyono. 2007. Metode Penelitian Bisnis. Bandung: Alfabeta.

Sulistyanto, S. 2008. Manajemen Laba; Teori Dan Model Empiris. PT Grasindo. Jakarta.

Suta, A.Y., dan Laksito, H. 2012. Analisis Faktor-Faktor yang Mempengaruhi Luas Pengungkapan Informasi Sukarela Laporan Tahunan. Diponegoro Journal Of Accounting. Vol.1, No.1.

Scott, W.R. 2009. Financial Accounting Theory, Fifth Edition. Prentice Hall. USA.

Shleifer, A., and Visny, R.W. 1997. A Survey of Corporate Governance. The Journal of Finance 52(2).

Uyar, A., dan Kilic, M. 2012. Influence of Corporate Attributes on Forward-Looking Information Disclosure in Publicly Traded Turkish Corporations. Procedia-Social and Behavioral Sciences 62:244-252.

Yularto, P.A., dan Chariri, A. 2003. Analisis Perbandingan Luas Pengungkapan Sukarela dalam Laporan Tahunan Perusahaan Yang Terdaftar di Bursa Efek Jakarta Sebelum Krisis dan pada Periode Krisis. Jurnal Manajemen Dan Sistem Informasi. Vol.2. 